DOI: $10.1515 / \mathrm{abcsj}-2015-0005$

\title{
The Counter-Hegemonic Virtues of Popular Culture in Eighteenth-Century England
}

\author{
DRAGOȘ IVANA
}

University of Bucharest

\begin{abstract}
The purpose of this article is to re-examine popular culture in earlymodern England by focusing on the oral/illiterate-written/literate and popular culture-high culture dyads. I aim to question why these interrelated socio-cultural categories have not been properly reconciled by the writers of the time. Moreover, my purpose is to focus on antiquarianism as a valid method whereby the delineation between the above-mentioned dichotomies turns into a subtle relationship in which both terms become complementary. I shall focus on two important antiquarian texts - Henry Bourne's Antiquitates Vulgares (1725) and John Brand's Observations on Popular Antiquities (1777) - by considering issues of religion and national identity, in an attempt to show that popular culture made known its counter-hegemonic virtues which, though permanently negotiated, were never rejected by the polite. Ultimately, the unstable relationship between the high and the low will be seen as suggestive of the porous boundaries between the two, indicating, at the same time, popular culture's participatory role in rethinking cultural identity in Enlightenment England.
\end{abstract}

Keywords: early modernity, popular culture, high culture, antiquarianism, orality, superstition, irrationality, literacy, politeness, cultural identity

In an article published in The Guardian on 28 October 2000, John Mullan contends that popular culture is coextensive with the self-sufficient yet permissive high culture taken as the sole marker of socio-historical contingency: 
Perhaps there has always been popular culture. Preserved in the amber of high literature and art are the traces of the lower amusements of the past.... Yet the idea that "the common people" might have a culture (rather than just habits of rowdyism) dates from precisely the time when our idea of high culture was being invented. Popular culture has always been its ill-mannered twin. (Mullan)

Far from falling into the trap of poststructuralist cultural relativism, Mullan's cogent perception and theorization of popular culture in tandem with, rather than in stark contrast to, high culture may look like an exercise in eighteenth-century antiquarianism, the scientific discipline interested in historical facts and, most notably, artefacts. Despite being "its ill-mannered twin," popular culture acquires, in the words of Mullan, the status of a legitimate and functional historical alternative to high culture, which gestures towards a reconciliation between the two, particularly when the high and the low are read appropriately in the cultural context of eighteenth-century England. Furthermore, as Mullan remarks, the high-low polarity becomes fluid when "high literature and art," or the written/literate mode of communication, records "the traces of the lower amusements of the past" disseminated by oral/illiterate culture.

In this article, my task is to rework the concept of popular culture from a twofold perspective. On the one hand, I aim to show how eighteenth-century perceptions of oral and written traditions intersect, and are interpreted both in the age and by contemporary scholarship, as a result of the emergence of certain significant socio-cultural factors that are deemed as the harbingers of classical modernity. On the other, I make the case that antiquarianism is able to shed light on the difficulty of interpreting the ambiguous relationship between high culture and popular culture. In doing so, I insist on the discourse advocated by eighteenthcentury religion and national identity, in an attempt to demonstrate that popular culture did promote its counter-hegemonic virtues, which were incessantly negotiated, yet never dismissed by the mainstream discourse of the elite. The permanent shuttling between the high and the low will thus be a prevalent feature meant to highlight not only the porous boundaries between the two but also popular culture's participatory role in rethinking cultural identity in Enlightenment England. 
At the dawn of the eighteenth century, spoken and written language were conceptually indicative of two divergent climates of opinion about the two modes of communication. Samuel Johnson's 1755 Dictionary defines "oral" as "delivered by mouth; not written." "Prior to this," argues L.I. Davies, "although it was acknowledged that the oral and literate differed as modes of transmission, accounts of linguistic structure and development were constructed primarily with reference to written modes" (305). Accounts related to the former climate of opinion claim that the relationship between oral and written culture should be placed within the melioristic and progressivist account of (early) modern civilized society built on the shattered foundation of primitivism, barbarianism, ignorance and superstition. In stark contrast to this theory posited by historians and antiquarians alike, pre-Romantic philosophers like Jean Jacques Rousseau staunchly believed in the decline, rather than stimulation and development, of artistic creativity and humanity, once oral culture was totally eradicated. Both the former's presentist bias and the latter's conservative and backward-oriented approach evince, as Davies pertinently points out, an "overlaying of attitudes" which "is dependent on the fact that the key feature of 'popular culture' was held to be its anachronistic reliance upon oral tradition and oral practices" (Davies 306, my emphasis). Yet, the triumphant discourse of eighteenth-century modern society, scientific rationality, empirical knowledge, politeness and religious secularism labelled oral tradition and practices as inferior, superstitious, vulgar and dangerous, since they were the exclusive preserve of the boisterous crowd.

Such conflicting attitudes have been thoroughly examined by contemporary scholars who, along with Mullan, view them as two interrelated accounts of eighteenth-century English popular culture. For instance, Peter Burke's seminal book entitled Popular Culture in Early Modern Europe (1978) is the first to propose such a shift of emphasis. Binary oppositions like primitive/modern, savage/civilized, illiterate/ literate, low/high, plebeians/patricians, popular/elite, aristocracy/the common people break down because, argues Burke, "the borderline between the different cultures of the people and the cultures of the elites (which were no less various) is a fuzzy one, so the attention of students of 
the subject ought to be concentrated on the interaction rather than the division between the two" (Burke 7). By the same token, sociologist Barry Reay maintains that "historians have not been sufficiently alert to the myriad ways in which orality suffused the world of print" (Reay 55). Similarly yet covertly, John Mullan expounds on "the traces of the lower amusements of the past," urging us to "look into Shakespeare, Hogarth or Dickens and you can see the remnants of popular diversions: ballads and songs, fairs and pantomimes, sports and ingenious forms of cruelty to animals" (Mullan). Collecting ancient ballads and folksongs was indeed a common antiquarian practice in the eighteenth century, which brought a massive contribution to renegotiating the relationship between "oral" and "the world of print." Ruth Perry's study published in 2008 is a telling example, as she offers us a delightful insight into the text composition, structure and performance of Scottish ballads, which, yet again, erases the boundaries between refinement and vulgarity. Pat Rogers's challenging thesis posited in his Popular Culture in Eighteenth-Century England (1985) focuses on the huge impact of eighteenth-century verities and varieties of life on the high literature of the time. Rogers's tour de force shows how Hogarth's, Swift's and Pope's satire sharpens its shafts so as to ridicule demotic customs, practices and performances, such as masquerades, pantomimes, freak-shows, bear-baiting, boxing matches, newspapers, gossip and advertising, while also drawing heavily on them. Though portrayed through the lens of biting satire, such vulgar pastimes must be taken as the indispensable subject-matter for "the world of print" - an idea to which I shall return later - and, most significantly, as genuine samples of antiquarianism that speak volumes of the status quo. Embedded in this kind of modus vivendi, the plebeians' way of acting depicted by Rogers enables me to further the second part of my argument related to the benefits of an antiquarian investigation that is able to shed light on the fluid yet ambiguous relationship between the culture of the masses and the culture of the elite. In a nutshell, such an approach enables us to look into various culturemes, i.e. the broad sweep of rituals, protocols, social practices, customs and beliefs that act as small narratives of high culture in the Republic of Letters. 
Eighteenth-century antiquarianism has long been discussed in terms of a concatenation of objectivity and evidence imposed by literate culture and literature, on the one hand, and by the oral mode specific to the curios that had to be sought and examined. As Rosemary Sweet points out,

the brunt of antiquarian activity in the eighteenth century was not carried out by the members of the aristocracy, or even under their auspices. ... Aspiring antiquaries, however, were able skillfully to exploit their aristocratic patrons' self-conscious identification with the Augustan Age, and their flattering dedications which eulogised aristocratic taste and classical virtue also made clear the aristocratic responsibility to assist those who sought to recover the physical remnants of this antique past. (Sweet 165)

Engaged in handing down old knowledge to the younger members of the local community in order to boost awareness of their own roots, antiquarians appeared to keep the plebeians' cultural tradition alive, notwithstanding its serious adulteration caused not only by the burgeoning modern cultural and social institutions but also by the process of massive urbanization and industrialization that England witnessed in the latter part of the century. Such is the case of Henry Bourne's Antiquitates Vulgares (1725), which Sweet considers as "the starting point for subsequent studies of popular customs" (355). Acting like a field reporter, Bourne commits himself to describing "a few of that vast Number of Ceremonies and Opinions, which are held by the Common People" (Bourne ix), the result being an accurate radiography of the historical origins of contemporary practices and beliefs which, filtered through the lens of the patricians, are believed to undermine social, moral and religious order. One must admit that Bourne's ideas are in line with his own profession, which clearly shows a separation between his social and educational background and the type of culture and people he depicts. Well-versed in Latin, the Bible and a large number of literary and historical texts, Bourne was a curate of the Parochial Chapel of All Saints in Newcastle upon Tyne who extols English Protestantism and excoriates Catholicism and heathenism, as they are solely responsible for the perils and evils of gross superstition that animate the irrational and incredulous crowds. His mission is to "wipe off ... the Dust" that popular customs have contracted, 
to clear them of Superstition, and make known their End and Design" (x). Admittedly, Bourne strikes a hostile attitude towards the ill-mannered vulgus whose ignorance, impoliteness and vulgarity mirror the anachronistic relics "that were customary in the Days of our Fore-Fathers" (115). Not only does he lambaste lower-class culture, he also documents multifarious forms of entertainment, such as May Day perceived as an ancient heathen custom or pantomime accompanied by singing and dancing, which is traced back to an ancient Saturnalia festival whose preservation in modern times is indicative of the common people's moral degeneracy. Ultimately, Bourne juxtaposes "Stories of Apparitions and Ghosts" (76) with the oral tradition of storytelling typical of countryside life: "Stories of this kind are infinite, and there are few villages which have not either had such a House in it, or near it" (41). By identifying the origins of such popular amusements, Bourne throws into relief "the logical inconsistencies within these practices, revealing the irrationality of their continued acceptance as a primary weakness of popular culture carried through oral tradition" (Davies 310).

Judged in religious terms, the "irrational acceptance" of popular culture via oral tradition is deep-seated in Catholicism, which for Bourne is the epitome of superstition and absurdity. Davies explains that "where the Protestant position is one of Sola Scriptura, the Catholic doctrine of apostolic succession ensures that oral pronouncements from within the church are directly tied to the word of God, and thus are of equal or even superior authority to the written word" (311). As a regulator of social and moral order, Bourne views things from a theological perspective which entitles him to claim that the Catholic faith fails to question its (pagan) origins whereas credulous believers, though not Catholic, continue to preserve a set of oral customs and beliefs which are outdated, utterly irrational and at loggerheads with Protestantism and the culture of print. By discriminating between the primitivism, illiteracy and orality of popular culture and the polite, genteel, literate and written culture of the elite, Bourne clearly demonstrates that he is a representative of high culture and that he writes from this perspective. Nevertheless, he draws attention to, and is acutely aware of, the power of the threatening crowd that perpetuates dangerous customs, practices and beliefs. Thus, the 
boundary that Bourne sets between the popular and the public seems to be drastic, if not limited.

Published 52 years after Bourne's study, John Brand's Observations of Popular Antiquities (1777) is a more comprehensive version of the former and, in the words of Sweet, "a significant landmark in the evolution of popular customs as a distinct area of inquiry" (Sweet 335). While Bourne undertakes to amend the corrupt culture of the vulgus, Brand is thoroughly dedicated to gathering relics and bringing to the fore the advancement of antiquarian pursuits. Like Bourne, however, he never fails to recognize the common people's immoderation and effervescent spirit that transform them into a threatening power. Unlike Bourne, whose major concern is to bolster the hegemonic virtues of Protestantism, Brand delves into popular antiquities by having recourse to politics. Thus, the plebeians' want of land and the right to vote represents one of the most noteworthy aspects of his enquiry. Seeking to define the concept of nation, Brand's analysis is in tune with contemporary opinions, according to which "political change was necessary to tackle corruption and restore virtue, and the idea that the public spirit had weakened, leaving the nation under threat from foreign attack and its liberty in peril, was a central Country tenet" (Davies 314). Luxury is, in Brand's opinion, the main cause which explains the waning of the public spirit. Perceived as a symbol of idleness, pleasure and even effeminacy at the time, luxury was there to fill the time of an affluent and genteel society and, implicitly, to sharpen the distinction between popular and public. Similarly, Mullen observes that "as pleasure became 'culture', it became increasingly important for the polite classes (many of them nouveaux riches) to distinguish between high and low entertainments" (Mullan). Brand lambastes the aristocratic taste for luxury and waste, since they hamper the progress of society's welfare and, worse, weakens the sense of national pride and civic solidarity. Paradoxically enough, he is an advocator of popular pastimes and sympathizes with the plebeians, who are held in high regard "when the general Spread of Luxury and Dissipation threaten more than at any preceding Period to extinguish the Character of our boasted national Bravery" (Brand vi). Far from posing as mere labourers who, according to the civic humanism tradition, are 
deprived of intellectual virtues and, particularly, imagination, since they are daily engrossed in burdensome work, Brand's common people embody "a politikon zoon" whose personal interests must coincide "with those of his fellow-citizens, considered in their ideal fulfilment" (Barrell 4). Treated as human, rather than brutes, their participation in the affairs of the polis is not deterred by the dispossession of property. This view is, as is the case with Bourne, highly limited because the crowd needs to be carefully policed, especially when it comes to action, which is immoderate and instinctual, and pastimes which, be they "innocent Sports and Games" or other popular amusements, are not aligned with history and contemporary taste. Like Bourne, Brand "surveys the scene of popular culture, picking those practices that seem harmless and potentially useful in rectifying the slippage towards the artifice and effeminacy of luxury, and discarding the rest" (Davies 315). Brand selects inoffensive sports and practices for pragmatic or utilitarian purposes related to an increase in labour efficiency and labour discipline, which were turned into norms in the last quarter of the eighteenth-century, when vulgar - and superstitious - leisure pursuits and social practices were regarded as a way of wasting time and energy. As shown, Brand blasts luxury as the exclusive privilege of a corrupt government, but, at the same time, he criticizes the common people for the same wasteful preoccupations. Davies summarizes this point as follows:

In this way, concerns regarding efficiency and wastefulness, as well as labor and leisure, are brought to bear upon one another in such a way as to cut across the division between popular and elite. If the labor and leisure of the common people are governed by the same standards as those for the elite, and have the potential to influence the "spirit" and "pride" of the nation as a whole, it becomes possible to reconcile the contradiction in the term "people" and incorporate the "vulgar" within the realm of the "public." (Davies 318-319)

Though very restrictive with respect to the liberties afforded to plebeians, the two texts under scrutiny fail to properly define the relationship between "popular" and "public." Notwithstanding the tensions that abound in Bourne's and Brand's texts, "popular" and "public" are always seen as interwoven categories. Under the auspices of 
antiquarianism, which often adopted the vantage-point of the polite, the "popular" was contextualized within the boundaries of the printed text, being thus deprived of its menacing power exercised on the polite audience. Incorporated "within the realm of the 'public'," as Davies says, popular culture was the sine qua non of literature, most notably, the novel. A demotic genre per se patented in the England of the 1740s, the novel borrowed its subject matter from the banal incidents of daily life recorded with much alacrity by Mr. Spectator, Joseph Addison's newspaper persona. According to Mullan, "the most successful novelist of that century, Samuel Richardson, was an uneducated self-made man who obsessively rewrote his books to purge them of colloquialism and inelegance. His detested rival, Henry Fielding ... cheerfully filled his novels with tavern scenes and coarse humour" (Mullan). Confined to "the world of print," the novel played a major role in intellectualizing popular amusements, practices, customs and beliefs that were there for the taking. It emerged as a result of an alternative cultural history which, in the words of William Warner, cogently shows "how a more general tendency of culture - the strife between 'high' and 'low' culture, the improving and the distracting, with the effort to sanction the first and inhibit the second may have developed characteristic modern forms in the eighteenth century" (Warner 294). Last but not least, there was Mr. Spectator, the detached observer of eighteenth-century life, who was alert to any small history unfolding in the middle of the street. Deeply rooted in daily lived experience, "the ill-mannered twin" of high culture thus proved its counter-hegemonic virtues and active role in the reshaping of the polite public sphere. Incorporated "within the realm of the public," it generated a new understanding of cultural identity in early-modern England, which ran counter to the belief - entertained by historians like William St Clair that "the members of the reading societies were the leaders of local life, a social, economic, and intellectual elite" (St Clair 258). 


\section{Works Cited}

Barrel, John. The Political Theory of Painting from Reynolds to Hazlitt: "The Body of the Public." New Heaven, Connecticut and London: Yale University Press, 1986. Print.

Bourne, Henry. Antiquitates Vulgares; Or, the Antiquities of the Common People. Giving an Account of Several of their Opinions and Ceremonies. With reflections upon each of them; shewing which may be retain'd, and which ought to be laid aside. Newcastle: J. White, 1725. Print.

Brand, John. Observations on popular antiquities: chiefly illustrating the origin of our vulgar customs, ceremonies, and superstitions. Rev. by Henry Ellis. London: F. C. and D. Rivington, 1813. Print.

Burke, Popular Culture in Early Modern Europe, $3^{\text {rd }}$ edn., London: Ashgate, (C) 1978, 2009. Print.

Davies, L.I. "Orality, Literacy, Popular Culture: An Eighteenth-Century Case Study." Oral Tradition 25/2 (2010): 305-323. Print.

Johnson, Samuel. A Dictionary of the English Language. 2 vols. London: J. and P. Knapton, 1755. Print.

Mullan, John. "The Invention of Popular Culture." The Guardian 28 Oct. 2000. Web. 24 Sept. 2015.

Perry, Ruth, "The Finest Ballads: Women's Oral Traditions in EighteenthCentury Scotland." Eighteenth-Century Life, 32.2, 2008: 81-97. Print.

Reay, Barry. Popular Cultures in England 1550-1750. London and New York: Longman, 1998. Print.

Rogers, Pat. Popular Culture in Eighteenth-Century England. Sussex: Harvester Press; New Jersey: Barnes and Noble, 1986. Print.

St Clair, William. The Reading Nation in the Romantic Period. Cambridge: Cambridge University Press, 2004. Print.

Sweet, Rosemary. Antiquaries: The Discovery of the Past in Eighteenth-Century Britain. London and New York: Hambledon and London, 2004. Print.

Warner, William. Licensing Entertainment: The Elevation of Novel Reading in Britain, 1684-1750. Berkeley, Los Angeles, Oxford: University of California Press, 1998. Print. 